\title{
EFFECTS OF MAGNESIUM AND TEMPERATURE DURING THE RECOVERY PROCESS FROM THE POTASSIUM CONTRACTURE OF THE PREGNANT RAT MYOMETRIUM
}

\author{
Takuro OsA \\ Department of Physiology, Faculty of Dentistry, Kyushu University, \\ Fukuoka 812, Japan
}

\begin{abstract}
Effects of external ions ( $\mathrm{Na}, \mathrm{K}, \mathrm{Mg}$ ) on the recovery from $\mathrm{K}$-contracture of the pregnant rat myometrium were investigated in Ca-free media. Relaxation was faster, when the external concentration of $\mathrm{Na}$ and $\mathrm{K}$ ions was higher. The time course of relaxation within a limited range of $60-20 \%$ of the mechanical output followed a single exponential function. The rate of relaxation, given by the reciprocal of the period during which the contraction decayed to $1 / \mathrm{e}$, was $0.3-0.5 \mathrm{~min}^{-1}$ at $34-35^{\circ} \mathrm{C}$ in isotonic $\mathrm{Na}$ solution. Low temperature caused prolongation of the relaxation, and the activation energy estimated on the rate of relaxation was $3-4 \mathrm{kcal} \cdot \mathrm{mol}^{-1}$. Relaxation became faster when $\mathrm{Mg}(0.5-20 \mathrm{~mm})$ was added to the relaxation media. Relaxation in isotonic $\mathrm{K}$ media was slower than in isotonic $\mathrm{Na}$ media, and the addition of $\mathrm{Mg}$ caused a slight acceleration of the relaxation. Low temperature caused an acceleration of the relaxation, irrespective of the presence or absence of external $\mathrm{Mg}$ ions. In low $\mathrm{K}$ media, where $\mathrm{K}$ ions were replaced by isosmolar sucrose, addition of $\mathrm{Mg}$ caused a significant acceleration of the relaxation. Activation energy ranged between $13-15 \mathrm{kcal}$. $\mathrm{mol}^{-1}$ in the solutions containing $\mathrm{Mg}$. This favors the existence of a relaxing system in pregnant rat myometrium that is $\mathrm{Mg}$ - and metabolismlinked.
\end{abstract}

Physiological and pharmacological results reported by previous investigators suggest that the tension development in smooth muscle tissues would be due to the release of $\mathrm{Ca}$, bound to plasma membrane as well as to intracellular organelles, on one hand, and transmembraneous Ca-influx on the other hand. In order to recover from contraction, the operation of the above-mentioned processes in an opposite way may be involved, but little is known about details (DURBIN and

Received for publication October 1, 1974

長 琢朗 
JENkinson, 1961; SchatzMANn, 1961; Edman and Schild, 1962; UraKAWA and Holland, 1964; Hurwitz et al., 1967; IMAi and TAKedA, 1969; MaGaribuCHI et al., 1973; VAN BREEMEN et al., 1973). Na-Ca exchange is a current topic of research (KATASE and TOMITA, 1972; ReUTER et al., 1973).

In the present report, effects of external ions, e.g., $\mathrm{Na}, \mathrm{K}$, and $\mathrm{Mg}$, on the recovery of the $\mathrm{K}$-contracture of the pregnant rat myometrium were studied. It was found that the presence of $\mathrm{Mg}$ ions in the bathing media caused a marked acceleration of the relaxation in a variety of ionic compositions except for high $\mathrm{K}$ concentrations. This effect was investigated in some detail with relation to the effects of temperature.

\section{METHODS}

Longitudinal strips of about $1 \mathrm{~mm}$ in width and $6 \mathrm{~mm}$ in length were excised from uteri of about 10-15 days pregnant rats. The preparation was mounted in an organ bath of $0.15 \mathrm{ml}$ capacity. Mechanical activity was transmitted to a mechano-electric transducer (Nihon Kohden, SB-1T), which in turn passed to a potentiometric pen-recorder (National Electronics, VP-652 B). Mechanical records were cut by scissors and superimposed graphically. Intracellular recording of the membrane activity was made by a conventional glass micro-electrode filled with $3 \mathrm{M} \mathrm{KCl}$, and the stimulating apparatus was according to the partition method described by ABE and Tomita (1968). In these cases, longitudinal strips of $3 \mathrm{~mm}$ in width and $7 \mathrm{~mm}$ in length were used.

The control bathing solution was a modified Locke Ringer, and other solutions served as contraction-inducing or relaxation-inducing media. The ionic composition chiefly used is given in Table 1. Examples of the abbreviation of contraction and relaxation media are shown in parentheses. All media listed in Table 1 contained $5.5 \mathrm{~mm}$ glucose. External $\mathrm{Na}$ and $\mathrm{K}$ ions were reduced by replacing them with isosmolar sucrose. Reduction of $\mathrm{Na}$ less than $8 \mathrm{~mm}$ contained as Na-bicarbonate was done by replacement with Tris-Cl. The Ca-free

Table 1. Ionic composition of control Locke solution (1), contraction-inducing media (2), relaxation-inducing media $(3 ; a, b)$. In parentheses, examples of the abbreviation of the media are illustrated. Concentrations of other constituents are described in METHODS.

\begin{tabular}{|c|c|c|c|c|c|c|}
\hline & $\mathrm{NaCl}$ & $\mathrm{NaHCO}_{3}$ & $\mathrm{KCl}$ & $\mathrm{CaCl}_{2}$ & $\mathrm{KHCO}_{3}$ & $\underset{(\mathrm{mM})}{\mathrm{MgCl}_{2}}$ \\
\hline 1. Control Locke Ringer & 154 & 8 & 5.6 & 2.2 & - & - \\
\hline $\begin{array}{l}\text { 2. Contraction media } \\
(\mathrm{K}, \mathrm{Ca})\end{array}$ & - & - & 159.6 & 2.2 & 8 & - \\
\hline $\begin{array}{l}\text { 3. Relaxation media } \\
\text { a) } \mathrm{Na} \text { solution }\end{array}$ & $0-161.8$ & 8 & - & $0-2.2$ & - & $0-20$ \\
\hline $\begin{array}{l}\text { b) } \mathrm{K} \text { solution } \\
(\mathrm{K}, \mathrm{Ca} \text {-free })\end{array}$ & - & - & $0-161.8$ & - & 8 & $0-20$ \\
\hline
\end{tabular}


media were prepared by omitting $\mathrm{Ca}$ and adding $1 \mathrm{~mm}$ EGTA (GEDTA, Dojin Pharm., Co.), which was titrated by Tris to yield a $\mathrm{pH}$ of 7.3. $\mathrm{Mg}$ ions were added only to the relaxation media. Because $\log \mathrm{K}$ (stability constant) of EGTA is 11.0 for $\mathrm{Ca}$, and 5.2 for $\mathrm{Mg}$, the chelating action should be much smaller on $\mathrm{Mg}$ to leave the ion in an ionized form. Solutions were equilibrated with a mixture gas of $3 \% \mathrm{CO}_{2}+97 \% \mathrm{O}_{2}$ in reservoirs, and the $\mathrm{pH}$ was 7.3. The flow of bathing media was $20 \mathrm{ml} / \mathrm{min}$; therefore, the exchange of the bulk solution in the organ bath should be finished within several sec. The temperature of the bathing media was varied between $36^{\circ}-21^{\circ} \mathrm{C}$ by using a thermo-regulating apparatus and was measured in succession by the thermistor thermometer (Nihon Kohden, MGA III). During a set of experiments, the temperature varied within a limit of $\pm 0.3^{\circ} \mathrm{C}$.

\section{RESULTS}

Effects of external $\mathrm{Na}$ and $\mathrm{K}$ ions on the recovery from the $K$-contracture

In the isotonic $\mathrm{K}$ media containing $2.2 \mathrm{~mm} \mathrm{Ca}$, the pregnant rat myometrium undergoes the tonic contraction succeeding the phasic contraction. All of the following results are concerned with the recovery from the K-contracture, which lasted for 5-10 min previously. The tonic contraction was terminated when the preparation was exposed to $\mathrm{Ca}$-free media containing either isotonic $\mathrm{Na}$ or isotonic $\mathrm{K}$ ions (Fig. 1). When the step of adding $\mathrm{Ca}$ was omitted, the contaminating amount of external $\mathrm{Ca}$ still affected the results. Therefore, unless otherwise

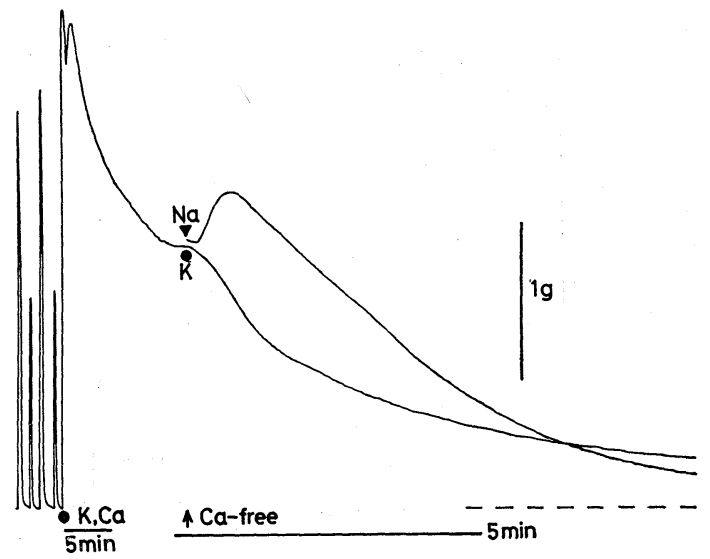

Fig. 1. The recovery from $\mathrm{K}$ contracture in Ca-free $(1 \mathrm{~mm}$ EGTA added $)$ media. Filled triangle and circle indicate the time when the isotonic $\mathrm{Na}$ or isotonic $\mathrm{K}$ solutions was applied. Records were superimposed graphically, and the K-contracture in the other trial was omitted. Note that faster sweep of pen-writing paper was started about $20 \mathrm{sec}$ before the exposure to the relaxation media. This applies to the following records. Dashed line represents the resting tension level. Unless otherwise described, temperature was $35^{\circ} \mathrm{C}$ in the present and following experiments. 
described, $1 \mathrm{~mm}$ EGTA was further added to Ca-free, $\mathrm{K}$ media in the present and following experiments. The time sequence of relaxation in $\mathrm{Ca}$-free isotonic $\mathrm{Na}$ solution differed from that in isotonic $\mathrm{K}$ solution by the preceding phasic contraction. However, about $3 \mathrm{~min}$ after exposing the tissue to $\mathrm{Ca}$-free media, the relaxation occurred at a faster rate in isotonic Na solution. When the time course of the recovery was plotted on a logarithmic scale against the period of the ex-

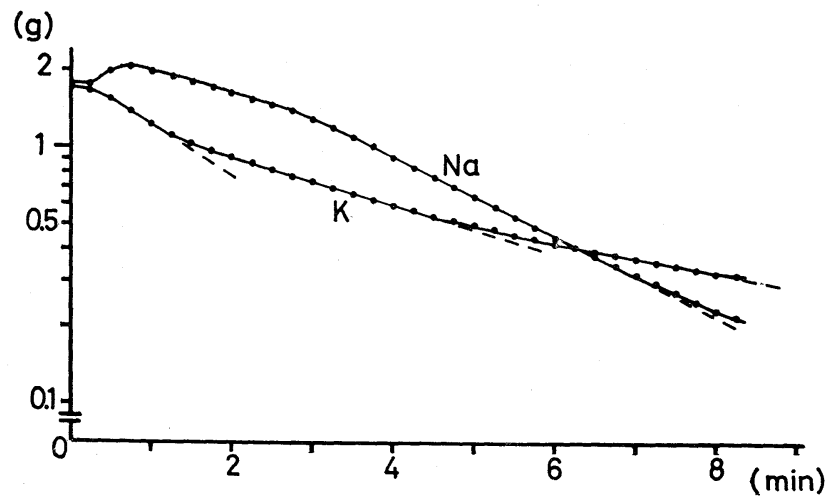

Fig. 2. Semilogarithmic presentation of the time course of the recovery (ordinate) against the exposure period to $\mathrm{Ca}$-free isotonic $\mathrm{K}$ or isotonic $\mathrm{Na}$ media (abscissa). The relations were derived from the results shown in Fig. 1. Dashed lines represent the extrapolation of exponentials.

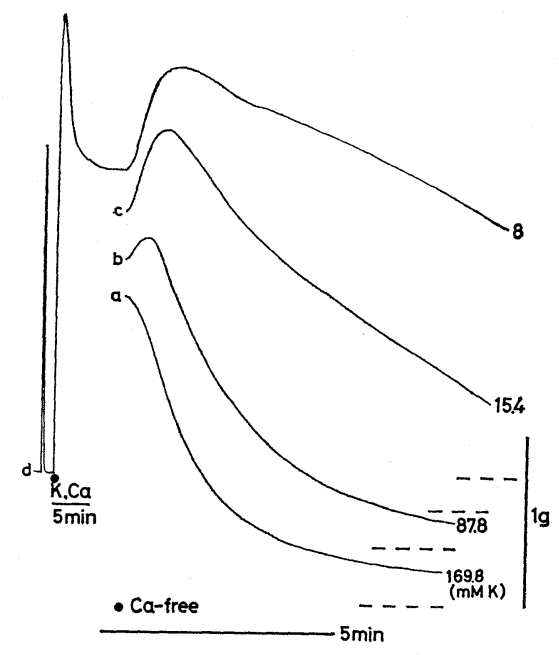

Fig. 3. Effects of external $\mathrm{K}$ concentration on the relaxation. Filled circle indicates the time when the application of Ca-free media containing various concentrations of external $\mathrm{K}$ was started. Numerical figures to the right represent the $\mathrm{K}$ concentrations in mM. Dashed lines from top to bottom are the resting tension levels for the records d to a. 
posure to the relaxation media, the relation in the $\mathrm{Na}$ solution was linear in the range between $1.5-0.3 \mathrm{~g}$ of the mechanical output (Fig. 2). The relation in the $\mathrm{Ca}-\mathrm{free}, \mathrm{K}$ solution was more complicated in the present result, apparently manifesting three exponentials.

The effects of external $\mathrm{K}$ concentration on the relaxation was investigated by using the $\mathrm{Ca}$-free solution, in which $\mathrm{K}$ concentration was reduced by replacement with isosmolar sucrose (Fig. 3). The effects of lowering $\mathrm{K}$ were biphasic, one being the development of phasic contraction during the earlier period of exposure to low $\mathrm{K}$ media, the other the prolongation of relaxation.

\section{Effects of $\mathrm{Na}, \mathrm{Mg}$ ions and temperature}

The relaxation in isotonic $\mathrm{Na}$ media was remarkably affected by external application of $\mathrm{Mg}$ or $\mathrm{Ca}$ ions (Fig. 4). The relaxation was the slowest in Ca-free media (a) containing $0 \mathrm{~mm} \mathrm{Mg}$, and it was accelerated when those divalent cations were present in the relaxation media. The results are plotted on a semilogarithmic scale and shown in the graph. The curves of the recovery in either medium are not linear in the whole range. They were possibly composed of two exponentials, fast and slow ones during earlier and later periods, respectively. Concerning the fast exponential, which covered the range of 1.9-0.3 g of mechanical output, the rate of relaxation was slower in the following order: $\mathrm{Ca}$-free $(\mathrm{a})<2.2 \mathrm{mM} \mathrm{Ca}$ containing (d) $<9 \mathrm{~mm} \mathrm{Mg-containing} \mathrm{media} \mathrm{(c).} \mathrm{For} \mathrm{other} \mathrm{curves,} \mathrm{the} \mathrm{rate} \mathrm{of}$ relaxation in $3 \mathrm{~mm} \mathrm{Mg-containing} \mathrm{media} \mathrm{(b)} \mathrm{nearly} \mathrm{equalled} \mathrm{d} \mathrm{and} \mathrm{that} \mathrm{in} 2.2 \mathrm{~mm}$

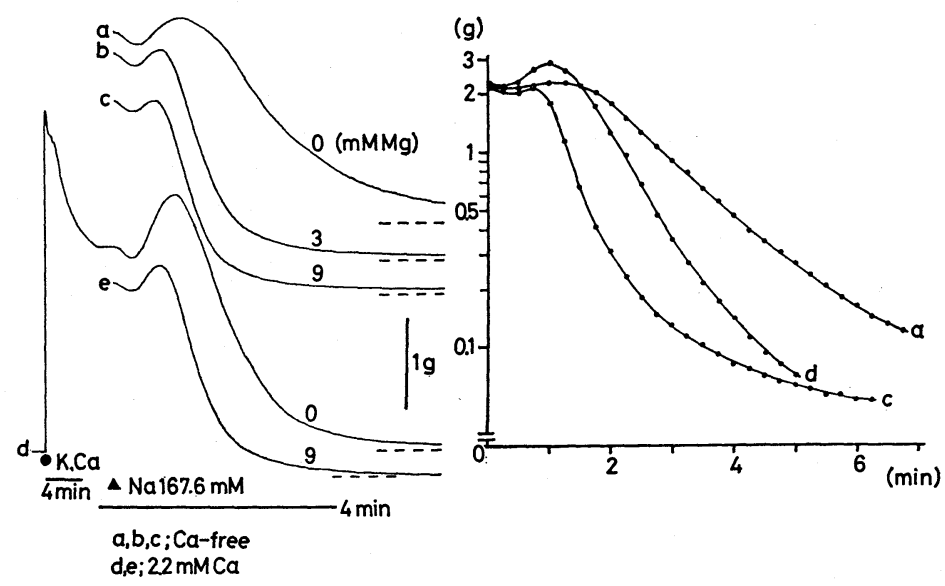

Fig. 4. Effects of $\mathrm{Mg}$ and $\mathrm{Ca}$ application on the recovery in the isotonic $\mathrm{Na}$ solution. For curves $\mathrm{a}, \mathrm{b}$, and $\mathrm{c}$, $\mathrm{Ca}$ was omitted and $1 \mathrm{mM}$ EGTA was added in relaxation media. $2.2 \mathrm{~mm} \mathrm{Ca}$ was present in cases of $\mathrm{d}$ and e, EGTA being absent. The time course is plotted on a semilogarithmic scale in the right graph. a, relation in $\mathrm{Ca}$-free, $\mathrm{Mg}$-free media; d, in $2.2 \mathrm{~mm}$ Ca containing $\mathrm{Mg}$-free media; c, Ca-free, $9 \mathrm{~mm} \mathrm{Mg}$ containing media. An example of $\mathrm{K}$-contracture is given in $\mathrm{d}$. 
Ca plus $9 \mathrm{~mm} \mathrm{Mg}(\mathrm{e}), \mathrm{c}$. It is furthermore indicated that $\mathrm{Mg}$ depressed the phasic contraction. In two other experiments, it was found that $\mathrm{Mg}$ as low as $0.1 \mathrm{~mm}$ was effective in causing the acceleration of the relaxation, and the effect persisted until the $\mathrm{Mg}$ concentration was increased up to $20 \mathrm{~mm}$.

The membrane was depolarized to $-30 \mathrm{mV}$ in $\mathrm{Ca}-$ free isotonic $\mathrm{Na}$ solution, and it was repolarized when $\mathrm{Mg}(0.1-9 \mathrm{~mm})$ was applied (Fig. 5). The amount of repolarization, underlying the decrease in the membrane conductance, was larger when the $\mathrm{Mg}$ concentration was higher. Therefore, the present result is in accord with the general concept of $\mathrm{Mg}$ action in the membrane stabilization.

The effects of external $\mathrm{Na}$ concentrations on the relaxation investigated in the experiment are shown in Fig. 6. The relaxation media contained $2.2 \mathrm{mM} \mathrm{Mg}$ in place of $\mathrm{Ca}$. The effects of low $\mathrm{Na}$ were again biphasic, i.e., the generation of phasic contraction and the prolongation of the relaxation. As to the phasic contraction, it was preceded by a transient relaxation in a high range of $\mathrm{Na}$ concen-

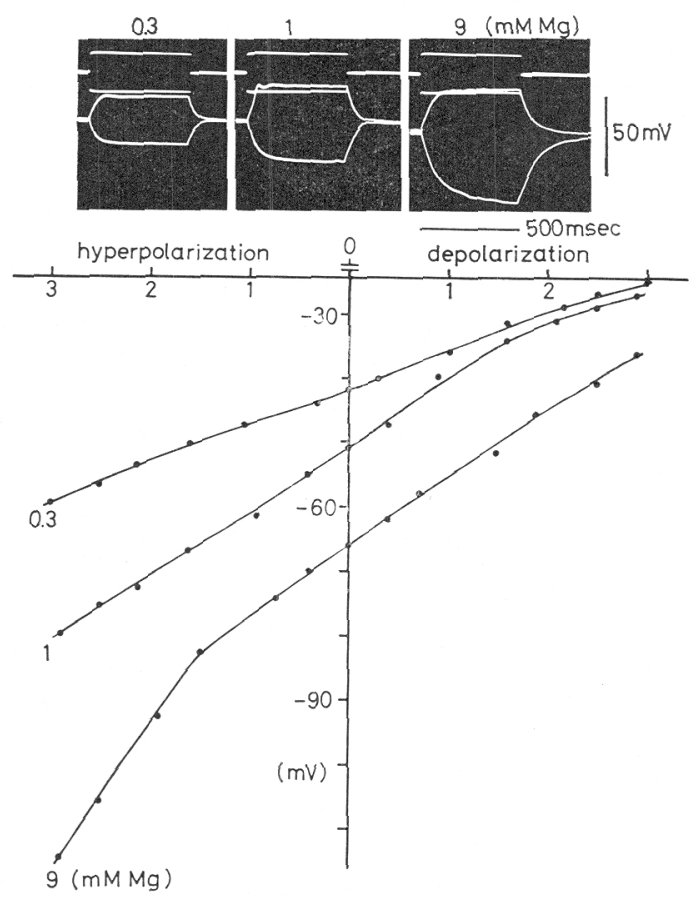

Fig. 5. Effects of $\mathrm{Mg}$ application $(0.3,1,9 \mathrm{~mm})$ to the isotonic $\mathrm{Na}$, Ca-free solution on the membrane potential and the electrotonic potentials produced in the longitudinal muscle cells by the external current application. Microelectrode was located $0.3 \mathrm{~mm}$ away from the stimulating electrode, and the records were from an identical cell. Responses were recorded after about $5 \mathrm{~min}$ equilibration in the test solutions. The membrane potential in Ca-free, Mg-free media was $-30 \mathrm{mV}$. The graph below shows the V-I relation, the intensity of stimulating current being given in arbitrary units. 


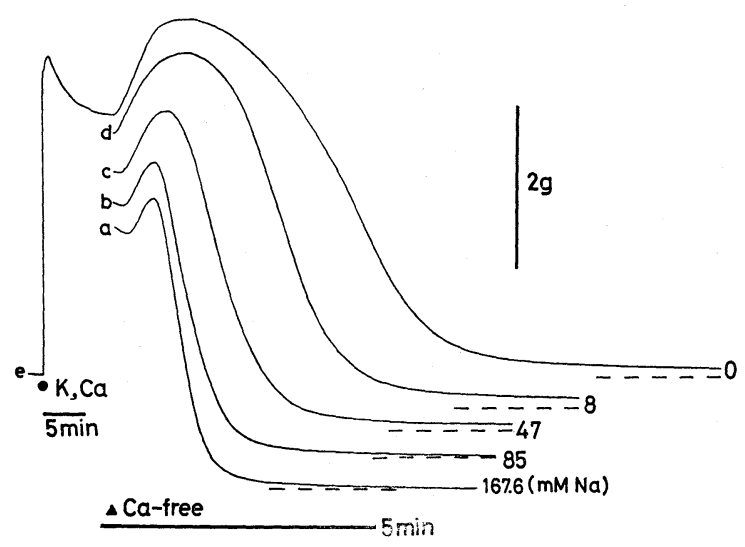

Fig. 6. Effects of external $\mathrm{Na}$ concentration on the recovery in Ca-free media. $3 \mathrm{~mm} \mathrm{Mg}$ was contained in the relaxation media. a, response in the isotonic Na solution; b-d, those in lower $\mathrm{Na}$ concentration, being shown to the right.

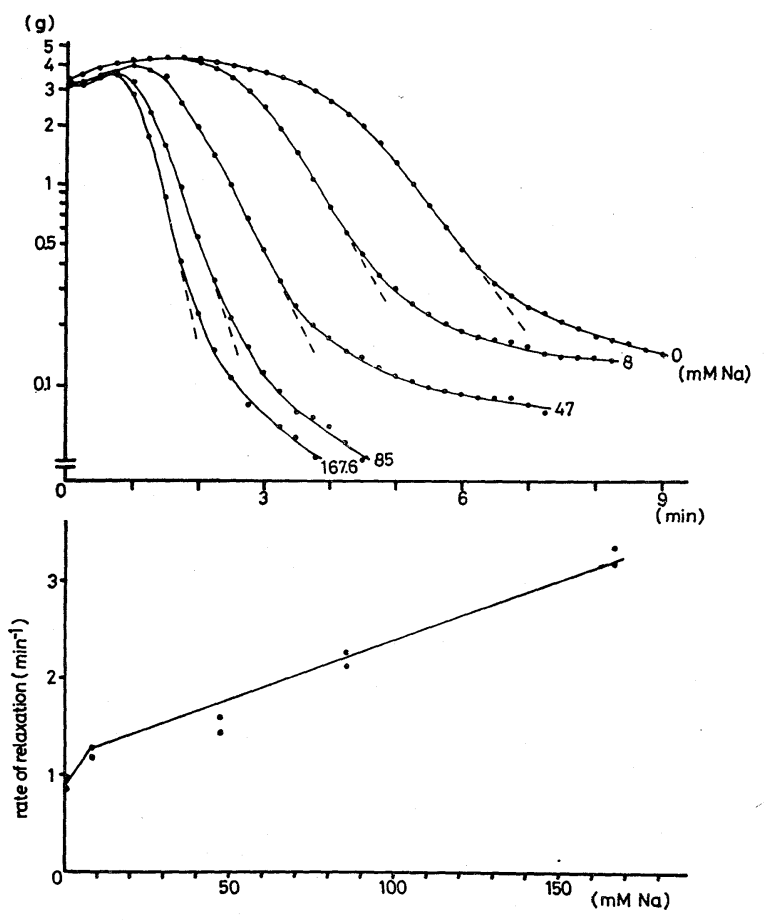

Fig. 7. Semilogarithmic presentation of the effects of external $\mathrm{Na}$ concentration on the recovery in Ca-free media plotted against the exposure period to relaxation media. For the linear part of the relation (extrapolated by dashed lines), $\tau_{c}$, which denotes the time during which the mechanical response decayed to $1 / \mathrm{e}$, was calculated and rate of relaxation $\left(1 / \tau_{c}\right)$ was deduced. The rates are plotted against the external $\mathrm{Na}$ concentrations (lower graph). 
tration $(a, b, c)$. The magnitude as well as the duration of phasic contractions were a function of the external $\mathrm{Na}$ concentration. Taking the present results together with those shown in Figs. 1 and 3, it is suggested that the removal of $\mathrm{K}$ (and $\mathrm{Na}$ ) ions was in some way responsible for the generation of the phasic contraction in $\mathrm{Ca}$-free media. The phasic contraction in the present experiment was possibly devoid of spike activity (OsA, 1973).

The results shown in Fig. 6 are plotted in Fig. 7 on a semilogarithmic scale against the exposure period in relaxation media. The relations followed a single exponential function in the range between $2-1.4 \mathrm{~g}$ of mechanical responses. The rate of relaxation was tentatively defined by the reciprocal of $\tau_{c}, \tau_{c}$ being the time during which the mechanical response fitting the earlier exponential decayed to 1/e. The rate of relaxation is definitely related to the external $\mathrm{Na}$ concentrations.

The effects of temperature on the relaxation in $\mathrm{Ca}$-free isotonic $\mathrm{Na}$ media studied in the experiment are shown in Fig. 8. The rate of the relaxation is shown in the Arrhenius plot, which shows a linear relation against $1 / \mathrm{T}$. The activation energy is estimated to be $3.2 \mathrm{kcal} \cdot \mathrm{mol}^{-1}$. Another finding was the enhancement of phasic contraction in the relaxation media with lower temperature. In contrast, temperature affected remarkably the time course of relaxation in isotonic $\mathrm{Na}$ media containing 3.0 mM Mg (Fig. 9). The Arrhenius plot (graph) gives an activation energy of $14.3 \mathrm{kcal} \cdot \mathrm{mol}^{-1}, \mathrm{Q}_{10}$ being 2.3. The effect of $\mathrm{Mg}$ and temperature was essentially the same in the low $\mathrm{Na}$ media, where $\mathrm{Na}$ ions were replaced by isosmolar sucrose. Activation energy varied between $13-15 \mathrm{kcal} \cdot \mathrm{mol}^{-1}$.

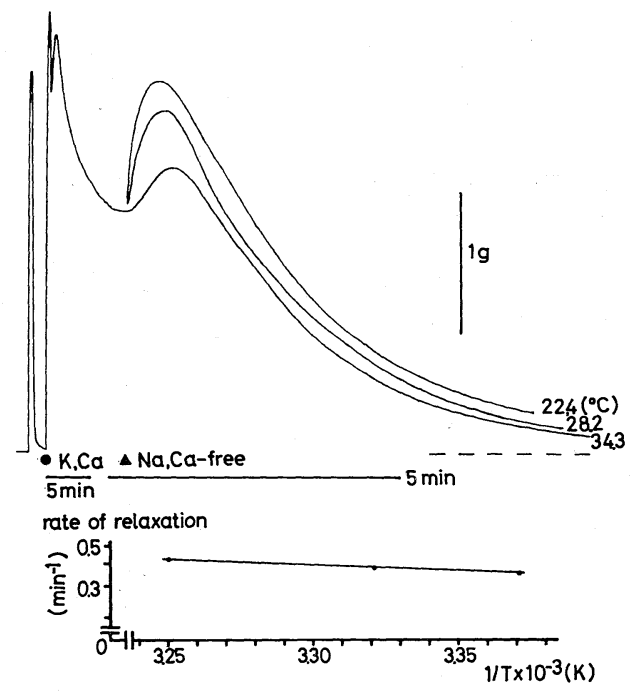

Fig. 8. Effects of temperature on the relaxation in $\mathrm{Ca}$-free, isotonic $\mathrm{Na}$ solution. The rates of relaxation $\left(1 / \tau_{c}\right)$ are shown in an Arrhenius plot (lower graph). Ordinate: logarithmic plot of the rate of relaxation. Abscissa: reciprocal of the absolute temperature. 


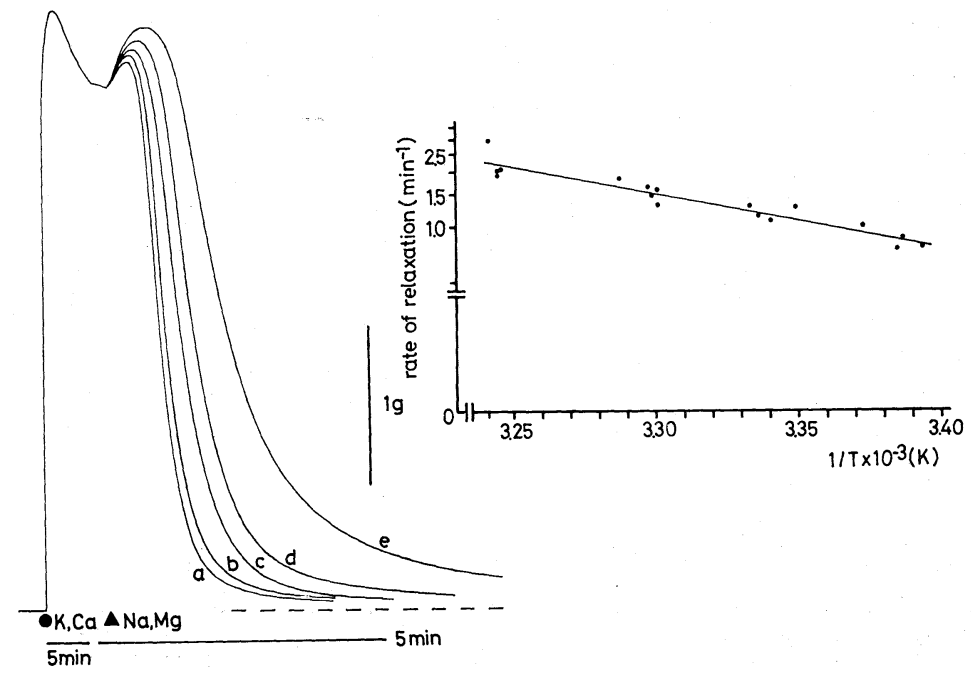

Fig. 9. Effects of temperature on the relaxation in $\mathrm{Ca}$-free media containing isotonic $\mathrm{Na}$ and $3 \mathrm{~mm} \mathrm{Mg}$. Temperature: a, 35.5; b, 31.2; c, 29.5; d, 25.6; e, $21.7\left({ }^{\circ} \mathrm{C}\right)$. Graph to the right shows the Arrhenius plot of the rates of relaxation. Results from the same preparation.

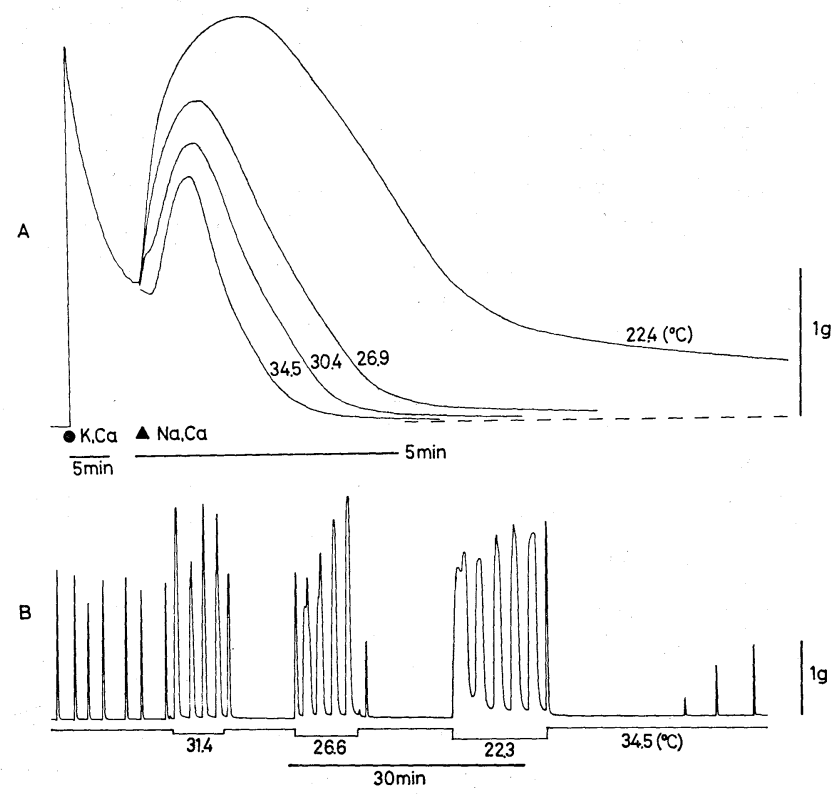

Fig. 10. Effects of temperature on the recovery from $\mathrm{K}$-contracture in the isotonic $\mathrm{Na}$ solution containing $2.2 \mathrm{~mm} \mathrm{Ca} \mathrm{(A).} \mathrm{Effects} \mathrm{of} \mathrm{lowering} \mathrm{temperature} \mathrm{on} \mathrm{the} \mathrm{spontane-}$ ous mechanical activity are shown in lower records (B). Note that the gain was halved in B. 
Strong dependency on temperature was also observed in the relaxation process in isotonic $\mathrm{Na}$ solution containing $2.2 \mathrm{~mm} \mathrm{Ca}$ (Fig. 10A). In the Arrhenius plot, the linear relation is disrupted at $22^{\circ} \mathrm{C}$, showing a smaller rate against $1 / \mathrm{T}$. In the linear part of the relation, the activation energy is estimated to be $7.7 \mathrm{kcal}$. $\mathrm{mol}^{-1}$. In the same preparation, the spontaneous mechanical activity in the control Locke solution was increased, and the base line tension interpolated between the periodic contractions was elevated when the temperature was lowered (B). When the bathing solution was rewarmed up to $34.5^{\circ} \mathrm{C}$, spontaneous activity ceased and it took several tens of min for the tissue to resume spontaneous contractions. Those events in the normal Locke solution were possibly due to the operation of the electrogenic $\mathrm{Na}$ pump, which has been proposed to exist in rat myometrium (TAYLOR et al., 1970).

\section{Effects of $\mathrm{K}, \mathrm{Mg}$ ions and temperature}

The relaxation of pregnant rat myometrium in Ca-free isotonic $\mathrm{K}$ media manifested a peculiar dependency on temperature (Fig. 11). The effect of $\mathrm{Mg}$ application was also different in isotonic $\mathrm{K}$ media (b) from that in isotonic $\mathrm{Na}$ media. In the first place, lowering the temperature generally caused an acceleration of the relaxation (a). The relation in terms of temperature was essentially the same, when $\mathrm{Mg}$ ions were present in the relaxation media (b). The faster relaxation process during the early period was abolished in the presence of $\mathrm{Mg}$ ions, which is most typically seen in the cases at $34^{\circ} \mathrm{C} \mathrm{(b} \mathrm{vs.} \mathrm{a).} \mathrm{When} \mathrm{plotted} \mathrm{in}$ semilogarithmic scale, the rate of relaxation during the later stage was increased only a little when $\mathrm{Mg}$ ions were present. The rate of relaxation was the fastest at $22^{\circ} \mathrm{C}$ in either the absence or presence of $\mathrm{Mg}$ ions. Phasic contractions were caused by low temperatures in accordance with the results shown in Fig. 8.

The effect of external $\mathrm{K}$ concentrations on the relaxation became complicated when $\mathrm{Mg}$ was applied simultaneously (Fig. 12a). The rate of relaxation was the

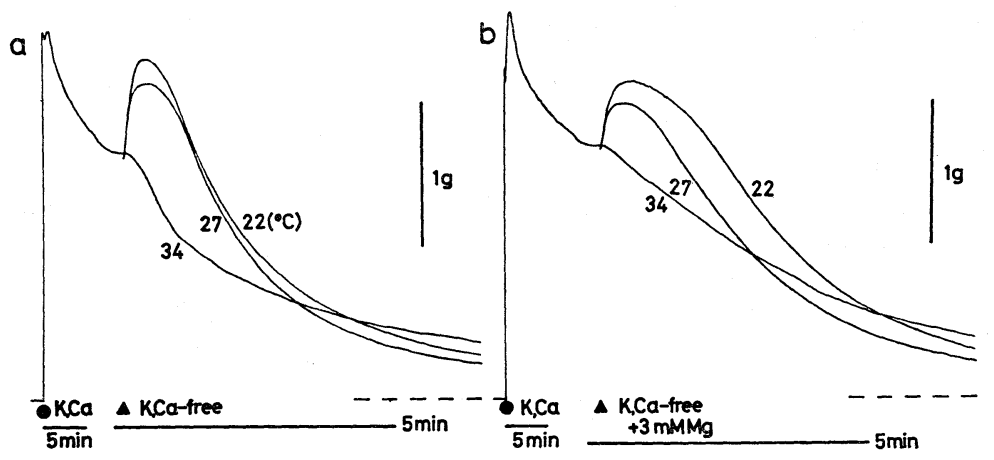

Fig. 11. Effects of temperature and $\mathrm{Mg}$ ions on the relaxation in the Ca-free media containing isotonic $\mathrm{K}$. For records in a, $\mathrm{Mg}$ was not contained in the relaxation media, and $3 \mathrm{~mm} \mathrm{Mg}$ was contained for records in $\mathrm{b}$. 
fastest when the $\mathrm{K}$ concentration was the lowest $(8 \mathrm{~mm})$. However, the situation was different when the relaxation media was cooled down to $22.5^{\circ} \mathrm{C}(\mathrm{b})$. The relation between the rate of relaxation and the external $\mathrm{K}$ concentration is graphically presented in Fig. 13 . At $22.5^{\circ} \mathrm{C}$, the rate of relaxation showed a smaller dependence on the external $\mathrm{K}$ concentration. At $34.5^{\circ} \mathrm{C}$, the rate of relaxation was the largest in $8 \mathrm{mM} \mathrm{K}$ solution. In contrast, low temperatures caused prolongation of relaxation in low $\mathrm{K}$ media when $\mathrm{Mg}$ was absent in the bathing media.

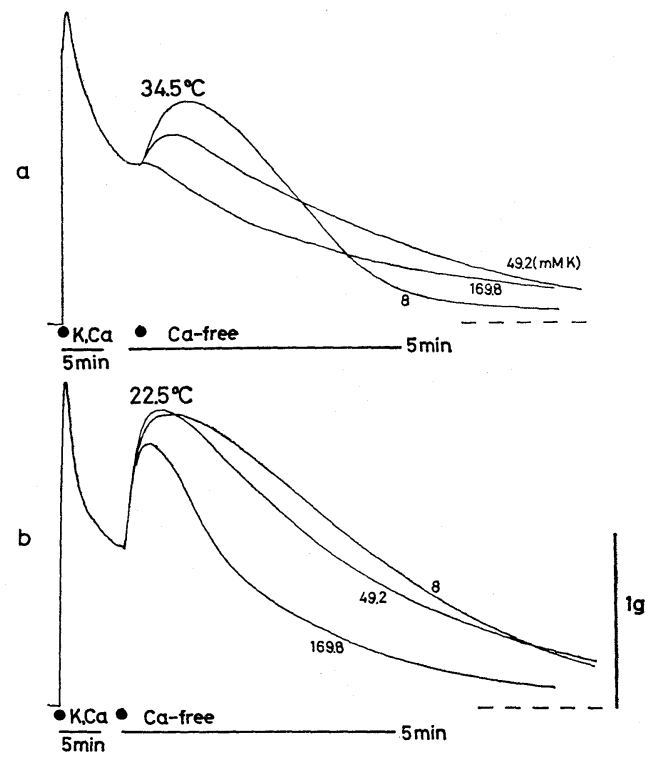

Fig. 12. Effect of temperature and external $\mathrm{K}$ concentration on the recovery in the Ca-free media containing $3 \mathrm{~mm} \mathrm{Mg}$. Results at two different temperatures: $34.5^{\circ} \mathrm{C}$ for a and $22.5^{\circ} \mathrm{C}$ for $\mathrm{b}$.

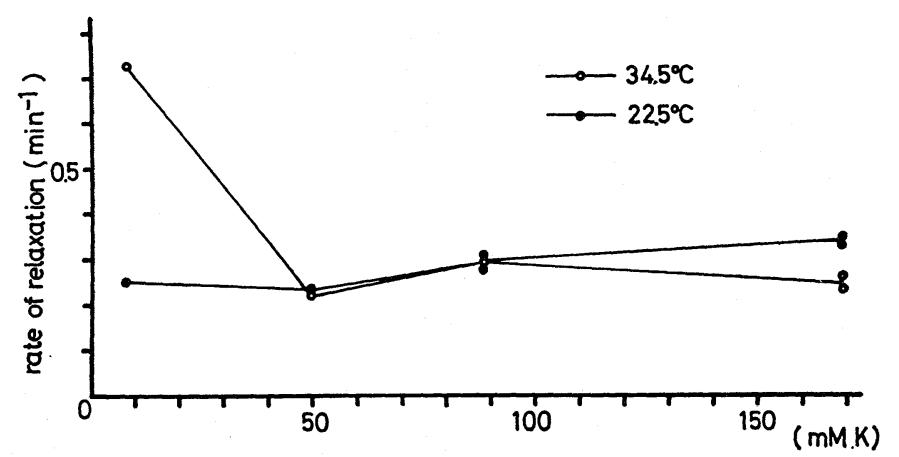

Fig. 13. Relation between the rate of relaxation and the external $\mathrm{K}$ concentrations at two different temperatures. Rates of relaxation were derived from the results shown in Fig. 12. 
The relations obviously resulted from the combined effects of the relaxation of the accelerating effect of $\mathrm{Mg}$, which was depressed in higher $\mathrm{K}$ concentration (Fig. 11) and the accelerating effect of $\mathrm{K}$ ions, which became dominant when the temperature was low (Figs. 3, 11). The use of $\mathrm{Mg}$ ions in the present experiments was sometimes to eliminate the time, and to prevent a change in the mechanical property during the prolonged exposure to artificial saline media (Fig. 6). Since external ion species possibly interact with each other in the processes of tension development and relaxation, further experiments are required to formulate a quantitative interrelationship.

\section{DISCUSSION}

On the assumption that tension development corresponds to an increase in intracellular free $\mathrm{Ca}$ ions, the phasic contractions evoked upon withdrawal of external $\mathrm{K}$ ions (Figs. 3, 4, 6) were most probably due to the release of $\mathrm{Ca}$ bound to the surface membrane. This is because the contractions were produced in Ca-free media and the magnitude was highly dependent on the ionic composition of the bathing media. On the other hand, because the phasic contraction in response to lowering temperature was less dependent on the external ionic composition (Figs. 8, 12), the Ca source responsible for that seems to originate possibly in other cellular structures, e.g., the intracellular organelles. Since detailed analysis was not made in the present experiments, the nature of the phasic contraction in the present context cannot be further examined, and the following discussion will be confined to the relaxation process.

Not only the mobilization of $\mathrm{Ca}$ from and to the membrane, but also the movement of the ions across the membrane are subject to the membrane potential (see for review, EBASHI and ENDO, 1968). There is an indication in the present results suggesting that relaxation occurred faster in the external ionic composition, where the membrane potential was more inside-negative. For example, relaxation was faster when divalent cations were added in Na-containing solution (cf., Fig. 8). Faster relaxation is likely a contradictory event from the membrane stabilization, when one assumes that the relaxation is due to diffusion process. Slow relaxation by $\mathrm{Mg}$ application as observed for the fast relaxation process in $\mathrm{Ca}$-free isotonic $\mathrm{K}$ solution (Fig. 11) was a single exception which favors the above concept. On the other hand, the relaxation also occurred faster in solutions which contained higher $\mathrm{K}$ and $\mathrm{Na}$ ions (Figs. 2, 6). No doubt, the membrane potential is dependent on the $\mathrm{K}$ gradient across the membrane, and the membrane of pregnant rat uterus is more inside-negative when external the $\mathrm{Na}$ is reduced (CASTEELS and KuRIYAMA, 1965; MARSHALL, 1963). Because the causal relationship between the rate of relaxation and ionic composition which in turn determines membrane potential seems indefinite at present, the effects of ions and temperature on the relaxation is approximated to occur under the direct influence of ions on the intracellular $\mathrm{Ca}$ regulation. The relaxation in Ca-free media containing isotonic $\mathrm{Na}$ had low 
dependency on temperature (Fig. 8), and this indicates the physical process. It is very possible that $\mathrm{Na}$-coupled $\mathrm{Ca}$ extrusion operated in the media containing $\mathrm{Na}$ ions (Figs. 6, 7). On the other hand, external $\mathrm{Na}$ was not a prerequisite for the relaxation ( $c f$. , guinea pig taenia coli, KATASE and Tomita, 1972; rabbit aorta, ReUTER et al., 1973). Probably several systems work for the recovery of Kcontracture in pregnant myometrium, and they are complemental in bringing about relaxation. It was suggested from the flux measurement that intracellular active-Ca accumulation by certain cellular structures, such as the vesicles close to the membrane, removes $\mathrm{Ca}$ from the cytoplasm of rat uterine smooth muscle (VAN BREemen et al., 1966). This process is said to be ATP-dependent (VAN BREEMEN et al., 1973), and much morphological background has been offered in a variety of smooth muscle tissues (DEvine et al., 1972). The loss of ${ }^{45} \mathrm{Ca}$ out of the ileal longitudinal muscle of guinea pig became faster in the media containing higher $\mathrm{Ca}$ concentrations. Furthermore, it was shown that the exchangeability of intracellular $\mathrm{Ca}$ was lower when external $\mathrm{Mg}$ was omitted (LüllmaNN and SiEgFrIEDT, 1968). It would be of interest if these events signify that the $\mathrm{Ca}$ extrusion was under the control of the relaxing system coupled with external divalent cations.

Temperature mainly affects the enzymatic activity related to the contractile activity. It was shown in the present experiment that the accelerating effect of $\mathrm{Mg}$ ions on the relaxation is characterized by strong dependency on the temperature (Figs. 9, 12), the activation energy being estimated to be $13-15 \mathrm{kcal} \cdot \mathrm{mol}^{-1}$, a value close to that reported for the binding of $\mathrm{Ca}$ ions by isolated sarcoplasmic reticulum (INESI and WATANABE, 1967). It has been demonstrated that the Ca binding to sarcoplasmic vesicles, which utilizes $\mathrm{ATP}$, needs $\mathrm{Mg}$ ions contained in incubation media (EBASHI, 1960; HasselbaCH and MAKInOSE, 1961). Therefore, it is highly probable that $\mathrm{Mg}$ ions were involved in a relaxing system of pregnant rat myometrium linked to the metabolism. However, it seems peculiar that the system was easily affected by external application of $\mathrm{Mg}$ ions. The change in the ionic composition of the bathing media may cause an alteration of the intracellular ionic composition in a parallel way, possibly because of the small surfacevolume ratio of smooth muscle cells, hence an amount of intracellular $\mathrm{Mg}$ concentration was attained. On the other hand, external $\mathrm{K}$ ions appear to depress the accelerating effect of $\mathrm{Mg}$ (Fig. 12). Therefore, an alternative site of $\mathrm{Mg}$ action would be, strange as it may seem, at the outer surface of a cell membrane. In line with this speculation, the interference between $\mathrm{Mg}$ and $\mathrm{K}$ ions may be parallel to the competition between the ionic species in the Mg activated ATP-ase of skeletal microsomal vesicle (CARVAlHo and LeO, 1967). Concerning this, the relative affinities such as $\mathrm{Ca}>\mathrm{Mg} \gg \mathrm{K}>\mathrm{Na}$ for the membrane sites have been determined in the guinea pig taenia coli, which led GooDFORD and WoLOWYK (1972) to emphasize a counter-cation hypothesis for the plasma membrane surface.

Low temperature accelerated the relaxation in Ca-free isotonic K-media (Fig. 
12), whereas it caused prolongation of the relaxation in low $\mathrm{K}$ media. Therefore, it should be said that an amount of external $\mathrm{K}$ ions or the consequent change in membrane potential is a prerequisite for the acceleration of the relaxation by lowering the temperature. It might be speculated that the effect of low temperature in high $\mathrm{K}$ media is due to the removal of metabolic support in maintaining the role of membrane as the diffusion barrier to ions.

In line with the above speculations, processes related to the elimination of intracellular-free $\mathrm{Ca}$ could be distinguished as follows: 1, Na-coupled $\mathrm{Ca}$ extrusion, which is not linked to metabolism; 2, Mg-linked Ca extrusion, linked to metabolism; 3, membrane-limited diffusion when external $\mathrm{K}$ concentration is high and the external $\mathrm{Ca}$ concentration is extremely low (Fig. 11), which may be affected by metabolic change. The former two would be physiologically significant. Of the artificial saline media for mammals, the lack of $\mathrm{Mg}$ ions in the Locke Ringer is one of the characteristics of this solution. It is very probable that the $\mathrm{Mg}$ action in the relaxation process and in the membrane stabilization can partially or wholly be taking place by $\mathrm{Ca}$ ions which are normally contained (Figs. 4, 5). When an experimental condition such as the use of Ca-free media in the mechanical investigation is considered, the neglect of the role of $\mathrm{Mg}$ ions leads to an omission of a factor among relaxing systems.

The author expresses his appreciation to Prof. H. Kuriyama for critical examination of the manuscript, and to Mr. K. Kitamura for help with calculations.

\section{REFERENCES}

AвE, Y. and Tomita, T. (1968) Cable properties of smooth muscle. J. Physiol., 196: 87-100.

Carvalho, A. P. and Leo, B. (1967) Effects of ATP on the interaction of $\mathrm{Ca}^{++}, \mathrm{Mg}^{++}$, and $\mathrm{K}^{+}$ with fragmented sarcoplasmic reticulum isolated from rabbit. J. Gen. Physiol., 50: 13271352.

Casteels, R. and Kuriyama, H. (1965) Membrane potential and ionic content in pregnant and non-pregnant rat myometrium. J. Physiol., 177: 263-287.

Devine, C. E., SomLYo, A. V., and Somlyo, A. P. (1972) Sarcoplasmic reticulum and excitationcontraction coupling in mammalian smooth muscles. J. Cell. Biol., 52: 69-718.

DuRbin, R. P. and Jenkinson, D. H. (1961) The calcium dependence of tension development in depolarized smooth muscle. J. Physiol., 157: 90-96.

EBASHI, S. (1960) Calcium binding and relaxation in the actomyosin system. J. Biochem., 48: $150-151$.

Ebashi, S. and ENDo, M. (1968) Calcium ions and muscle contraction. In Prog. Biophys. Mol. Biol., ed. by Butler, J. A. V. and Noble, D. Pergamon Press, Oxford and New York, pp. 123-183.

Edman, K. A. P. and Schild, H. O. (1962) The need for calcium in the contractile responses induced by acetylcholine and potassium in the rat uterus. J. Physiol., 161: 424-441.

GooDFORD, P. J. and WolowYK, M. W. (1972) Localization of cation interactions in the smooth muscle of the guinea pig taenia coli. J. Physiol., 224: 521-535.

HasselbaCH, W. and MAKINOSE, M. (1961) Die Calciumpumpe der 'Erschlaffungsgrana' des Muskels und ihre Abhängigkeit vom der ATP-spaltung. Biochem. Z., 333: 518-528. 
Hurwitz, L., Joiner, P. D., and von Hagen, S. (1967) Calcium pools utilized for contraction in smooth muscle. Am. J. Physiol., 213: 1299-1304.

IMAI, S. and TAKEDA, K. (1969) Actions of calcium and certain multivalent cations on potassium contracture of guinea-pig's taenia coli. J. Physiol., 190: 155-169.

INESI, G. and WATANABE, S. (1967) Temperature dependence of ATP hydrolysis and calcium uptake by fragmented sarcoplasmic membranes. Arch. Biochem. Biophys., 121: 665-671.

KATASE, T. and Tomita, T. (1972) Influences of sodium and calcium on the recovery process from potassium contracture in the guinea-pig taenia coli. J. Physiol., 224: 487-500.

LÜllmanN, H. and SIEGFriedt, A. (1968) Über den Calcium-Gehalt und den ${ }^{45}$ Calciumaustausch in Längsmuskulatur der Meerschweinchendünndarms. Pflügers Arch., 300: 108-119.

Magaribuchi, T., Ito, Y., and KuriYAma, H. (1973) Effects of rapid cooling on the mechanical and electrical activities of smooth muscle of guinea pig stomach and taenia coli. J. Gen. Physiol., 61: 323-341.

Marshall, J. M. (1963) Behaviour of uterine muscle in Na-deficient solutions; effects of oxytocin. Am. J. Physiol., 204: 732-738.

OsA, T. (1973) Some factors affecting the contractile responses of pregnant mouse myometrium. Jap. J. Physiol., 23: 401-417.

Reuter, H., Blaustein, M. P., and Heusler, G. (1973) Na-Ca exchange and tension development in arterial smooth muscle. Phil. Trans. R. Soc. Lond. B., 265: 87-94.

SchatzmanN, H. J. (1961) Calciumaufnahme und Abgabe am Darmmuskel des Meerschweinchens. Pflügers Arch. Ges. Physiol., 274: 295-310.

Taylor, G. S., Paton, D. M., and Daniel, E. E. (1970) Characteristics of electrogenic sodium pumping in rat myometrium. J. Gen. Physiol., 56: 360-375.

Urakawa, N. and Holland, W. C. (1964) $\mathrm{Ca}^{45}$ uptake and tissue calcium in K-induced phasic and tonic contraction in taenia coli. Am. J. Physiol., 207: 873-876.

Van Breemen, C., Daniel, E. E., and Van Breemen, D. (1966) Calcium distribution and exchange in the rat uterus. J. Gen. Physiol., 49: 1265-1297.

Van Breemen, C., Farinas, B. R., Casteels, R., Gerba, P., Wuytack, F., and Deth, R. (1973) Factors controlling cytoplasmic $\mathrm{Ca}^{2+}$ concentration. Phil. Trans. R. Soc. Lond. B., 265: 57-71. 